\title{
油脂と溶媒との混合容積
}

草 野 一 仁*

\section{Volume of Mixing Fatty Oil with Various Solvents}

\section{Kazuhito Kusano}

\section{1. 緒言}

一般飞油脂と溶媒とは分子の形括よび大きさが異なっ ているから，両者を混合してできる溶液の物理化学的な 諸性質は, 理想溶液のそれから偏倚するであろうことは 容易に想像される。事実混合熱は 0 でなく ${ }^{12,2), 3) ， ま た ~}$ 溶液の蒸気圧も ラウールの法則飞従わな(4),51,67,7),8)。 さらにまた混合溶液の容積も, 成分の容積の和にならな (1),9),109,11),12),133,14)。乙たがって混合飞伴う容積変化を 測定することは, 油脂溶液の物理化学的特性を明らか反 するために必要であるばかりでなく, それを求める過程 に颃いて測定される溶液の密度は, 工業上に和いて必要 な基礎的数值を与えるものである。

油脂溶液の密度, したがって, 比容あるいは混合に伴

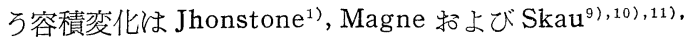
${ }^{12)}$, 宮崎 ${ }^{13)}$, Arnold $^{14)}$ らとよって測定されてきた。特 飞 Skau らは, 多くの油脂を各種の溶媒と混合してそ の密度を測定し, 油脂と溶媒との混合に伴う容積変化を 求め, これに関する一般式を提出した ${ }^{12)}$ 。なわち混合 に伴う容積変化 $\Delta_{m} V$ ほ油脂の種類に関係せず溶媒に よって異なるが， $\Delta_{m} V$ の極值は重量分率に括いて 0.5 の点にあり，ここを頂点として左右対称な放物線をなす というのである。しかし，これらの測定はいずれる測定 の䛊差が大きく, 測定者によってはとの符号さえる異な ることがある。したがって油脂一溶媒系の物理化学的諸 特性を計算するための基礎数值としては不充分であると 思われるので， あらためて精密測定を行なった。

\section{2. 実験装置および方法}

$\Delta_{m} V$ の測定は混合溶液の密度を測定し, これから計 算して求める方法をとった。すなわち, 成分の比容, 重 量分率をそれぞれ $v_{1}, v_{2}, w_{1}, w_{2}$ とし, 両成分の混合 によって容積が変化しないとすれば, その全容積 $V^{i}$ は

$$
V^{i}=w_{1} v_{1}+w_{2} v_{2}
$$

となるが，一般には混合に伴う容積の変化があって全容 積は $V^{i}$ とならず，これより $\Delta_{m} V$ だけ異なった容積 $V$ を占める。V は溶液の比容であるから， $\Delta_{m} V$ を精密に

* 宮崎大学工学部工業化学教室(宮崎市西丸山町 118) Faculty of Engineering, Miyazaki University
求めることは, 結局溶液の密度 $\rho$ と成分の密度 $\rho_{1}, \rho_{2}$ とを精密に測定することに帰する。

密度の測定に使用した比重ビンは, 内容約 $12 \mathrm{cc}$ のス プレンゲルオストワルド型のもので, 両端の毛細管の内 径 $1 \mathrm{~mm}$ ，すり合わせフタ付のテレックスガラス製のも のである。約 10 個を作って，この中から特とすり合わ せの良い 3 個を選んで用いた。テンビンは守谷製化学テ ンビン, ヒョウ(科)量 $100 \mathrm{~g}$ ののを末使用のまま 8 年 枯らしてのち, 充分衤補正を施したものと,ザルトリウス 製微量テンビンに補正を施したものとを使った。実験に は主として前者を用い，ときどき同一試料を両テンビン で測定して測定に誤りのないことを確かめた。ヒョウ量 するときの各種の補正は常法に従ったが15) $\Delta_{m} V$ は

$$
\Delta_{m} V=V-V^{i}
$$

であって, $V$ と $V^{i}$ との差として与光られるから, その 測定精度を上げるためには, テンビンの腕比の温度なら びに荷重による変化, 空気密度に及ぼす温度, 大気圧, 湿度の影響，ならびに物の挌のの分銅の容積末でも考慮 し, さらとまた比重ビンを恒温ソウから出してのちの放 置時間, 放置状況などについても配慮した。これらの精 細については別と報告した ${ }^{16)}$ 。

\section{3. 試料}

油脂は代表として精製大豆油を用いた。その特数は

表-1 溶媒の物理的性質

\begin{tabular}{l|c|l}
\hline \multicolumn{1}{c|}{ 溶 } & 媒点 $\left({ }^{\circ} \mathrm{C}\right)$ & $\begin{array}{c}\text { 密 } \\
\left(\mathrm{g} / \mathrm{cm}^{3} \text { at } 30.0^{\circ} \mathrm{C}\right)\end{array}$ \\
\hline ベンゼン & 80.1 & $0.86866(0.86845)$ \\
シクロヘキサン & 80.7 & $0.76927(0.76928)$ \\
$n$-ヘキサン & $68.8 \sim 69.0$ & $0.65094(0.65482)^{\mathrm{a}}$ \\
四塭化炭素 & 76.7 & $1.57613(1.57480)$ \\
1,2-二塩化エタン & 83.5 & $1.24046(1.23831)$ \\
1,1,2,2-四塩化エタン & 146.0 & $1.57974(1.57860)$ \\
二硫化炭素 & $46.2 \sim 46.4$ & $1.24701(1.24817)$ \\
クロロホルム & 61.2 & $1.47104(1.47060)$ \\
トリクロルエチレン & $86.9 \sim 87.0$ & $1.44753(1.4514)$ \\
酢酸エチル & 77.1 & $0.88825(0.90455)^{\mathrm{a}}$ \\
アセトン & 56.3 & $0.78315(0.78508)^{\mathrm{a}}$ \\
\hline
\end{tabular}

カッコ内は文献値, $\mathrm{a}$ は $25.0^{\circ} \mathrm{C}$ の值 
は, ヨウ素価 134.9 (ハヌス法), ケン化価 189.6, 酸価 $0.01, n_{\mathrm{D}}^{20} 1.4755$ のものである。溶媒は無極性のものと して, ベンゼン, シクロヘキサン, $n$-ヘキサン, 四塩化 炭素, 1,2-二塩化エタン, 1,1,2,2-四塭化エタン, 特よ び二硫化炭素を, 極性のあるすのとしてクロロホルム, トリクロルエチレン, 酢酸エチル, 挔よびアセトンを使 用した。これらの溶媒は常法に従って精製した ${ }^{17)}$ 。とし てとの物理的性質は 表-1 に示すと括りである。

また密度測定の基準となる水は, 電導度用水の製法に 従って作り,使用に当っては煮沸して溶存空気を除いた。

\section{4. 測 定 結 果}

測定の結果を表-2〜表-12,ならびそ 図-1 飞示す。 これらの諸表中大豆油の比容が異なっているのは, 保存 中にそれが変化したためである。しかし比容以外の諸特 数にはその変化が皃とんぞ認められなかった。比容の実 測值はそれぞれ 3 個の比重ビンによる測定值の平均であ り, 測定誤差は有効数字の最後から 2 杕目で 2 以下, 測 定温度はすべて $30.0 \pm 0.001^{\circ} \mathrm{C}$ である。

表-2 大豆油一ベンゼン系混合容積 $\left(30.0^{\circ} \mathrm{C}\right)$

\begin{tabular}{c|r|r|r}
\hline $\begin{array}{c}\text { 大豆油 } \\
\begin{array}{c}\text { 重量分率 } \\
w\end{array}\end{array}$ & $\begin{array}{c}\text { 比容 積 } \\
\left(\begin{array}{c}\text { (測值 }) \\
V\left(\mathrm{~cm}^{3} / \mathrm{g}\right)\end{array}\right.\end{array}$ & $\begin{array}{c}\text { 理想溶液 } \\
\begin{array}{c}\text { 比容 } \\
V^{i}\left(\mathrm{~cm}^{3} / \mathrm{g}\right)\end{array}\end{array}$ & $\begin{array}{c}\text { 混合飞伴 } \\
\text { 容積変化 } \\
{ }_{m} V\left(\mathrm{~cm}^{3} / \mathrm{g}\right)\end{array}$ \\
\hline 0.00000 & 1.151198 & 1.151198 & 0.000000 \\
0.04962 & 1.148564 & 1.148344 & +0.000220 \\
0.21277 & 1.139472 & 1.138959 & +0.000513 \\
0.35844 & 1.131181 & 1.130580 & +0.000601 \\
0.54305 & 1.120594 & 1.119961 & +0.000633 \\
0.75531 & 1.108226 & 1.107752 & +0.000474 \\
0.84863 & 1.102722 & 1.102384 & +0.000338 \\
0.91026 & 1.099038 & 1.098839 & +0.000190 \\
1.00000 & 1.093677 & 1.093677 & 0.000000 \\
\hline
\end{tabular}

表-3 大豆油一シクロヘキサン系混合容積 $\left(30.0^{\circ} \mathrm{C}\right)$

\begin{tabular}{|c|c|c|c|}
\hline $\begin{array}{c}\text { 大豆油 } \\
\text { 重量分率 } \\
w\end{array}$ & $\begin{array}{l}\text { 毕容 積 } \\
\text { (赛測值) } \\
V\left(\mathrm{~cm}^{3} / \mathrm{g}\right)\end{array}$ & $\begin{array}{c}\text { 理想溶液 } \\
\text { 比容積 } \\
V^{i}\left(\mathrm{~cm}^{3} / \mathrm{g}\right)\end{array}$ & $\begin{array}{l}\text { 混合飞伴う } \\
\text { 容積変化 } \\
\Delta_{m} V\left(\mathrm{~cm}^{3} / \mathrm{g}\right)\end{array}$ \\
\hline 0.00000 & 1.299926 & 1.299926 & 0.000000 \\
\hline 0.10745 & 1.278232 & 1.277814 & +0.000418 \\
\hline 0.20186 & 1.259028 & 1.25 & +0.000641 \\
\hline 0.40795 & 1.216827 & 1.215976 & +0.000851 \\
\hline 0.60173 & 1.176973 & 1.176099 & +0.000874 \\
\hline 0.87159 & 1.120932 & 1.120566 & +0.000366 \\
\hline 1.00000 & 1.094142 & 1.094142 & 0.000000 \\
\hline
\end{tabular}

表-4 大豆油一 $n$-ヘキサン系混合容積 $\left(30.0^{\circ} \mathrm{C}\right)$

\begin{tabular}{c|c|c|r}
\hline $\begin{array}{c}\text { 大豆 油 } \\
\begin{array}{c}\text { 重量分率 } \\
w\end{array}\end{array}$ & $\begin{array}{c}\text { 比容 積 } \\
\left(\begin{array}{c}\text { 実測值 }) \\
V\left(\mathrm{~cm}^{3} / \mathrm{g}\right)\end{array}\right.\end{array}$ & $\begin{array}{c}\text { 理想溶液 } \\
\text { 比容 } \\
V^{i}\left(\mathrm{~cm}^{3} / \mathrm{g}\right)\end{array}$ & $\begin{array}{c}\text { 混合飞伴 } \\
\text { 容積変化 } \\
\Delta_{m} V\left(\mathrm{~cm}^{3} / \mathrm{g}\right)\end{array}$ \\
\hline 0.00000 & 1.536247 & 1.536247 & 0.000000 \\
0.09904 & 1.488645 & 1.492411 & -0.003766
\end{tabular}

\begin{tabular}{l|l|l|r}
0.19615 & 1.452400 & 1.459429 & -0.007029 \\
0.31592 & 1.387719 & 1.396417 & -0.008698 \\
0.39022 & 1.354428 & 1.363531 & -0.009103 \\
0.52307 & 1.295629 & 1.304731 & -0.009102 \\
0.60626 & 1.259046 & 1.267910 & -0.008864 \\
0.75302 & 1.196244 & 1.202952 & -0.006708 \\
0.85741 & 1.152000 & 1.156748 & -0.004748 \\
0.93809 & 1.118729 & 1.121038 & -0.002309 \\
1.00000 & 1.093636 & 1.093636 & 0.000000 \\
\hline
\end{tabular}

表-5 大豆油一四塩化炭素系混合容積 $\left(30.0^{\circ} \mathrm{C}\right)$

\begin{tabular}{|c|c|c|c|}
\hline $\begin{array}{c}\text { 大豆 油 } \\
\text { 重量分率 } \\
w\end{array}$ & $\begin{array}{l}\text { 此 容 積 } \\
(\text { 実測値) } \\
V\left(\mathrm{~cm}^{3} / \mathrm{g}\right)\end{array}$ & $\begin{array}{l}\text { 理想溶液 } \\
\text { 比容積 } \\
V^{i}\left(\mathrm{~cm}^{3} / \mathrm{g}\right)\end{array}$ & $\begin{array}{l}\text { 混合飞伴 } 5 \\
\text { 容積変化 } \\
\Delta_{m} V\left(\mathrm{~cm}^{3} / \mathrm{g}\right)\end{array}$ \\
\hline 0.00000 & 0.634464 & 0.634464 & 0.000000 \\
\hline 0.06384 & 0.663310 & 0.663796 & -0.000486 \\
\hline 0.12135 & 0.689375 & 0.690221 & -0.000846 \\
\hline 0.18967 & 0.720453 & 0.721612 & -0.001159 \\
\hline 0.32732 & 0.783350 & 0.784858 & -0.001508 \\
\hline 0.49816 & 0.861737 & 0.863354 & -0.001617 \\
\hline 0.58711 & 0.902625 & 0.904224 & -0.001599 \\
\hline 0.79197 & 0.997293 & 0.998351 & -0.001058 \\
\hline 0.91129 & 1.052677 & 1.053175 & -0.000498 \\
\hline 0.95815 & 1.074399 & 1.074706 & -0.000307 \\
\hline 1.00000 & 1.093935 & 1.093935 & 0.000000 \\
\hline
\end{tabular}

表-6 大豆油一1,2-二塩化エタン系混合容積 $\left(30.0^{\circ} \mathrm{C}\right)$

\begin{tabular}{|c|c|c|c|}
\hline $\begin{array}{c}\text { 大豆 油 } \\
\text { 重量分率 } \\
w\end{array}$ & $\begin{array}{l}\text { 毕容 皘 } \\
\text { (実測值) } \\
V\left(\mathrm{~cm}^{3} / \mathrm{g}\right)\end{array}$ & $\begin{array}{c}\text { 理想溶液 } \\
\text { の比容積 } \\
V^{i}\left(\mathrm{~cm}^{3} / \mathrm{g}\right)\end{array}$ & $\begin{array}{c}\text { 混合に伴う } \\
\text { 容積変化 } \\
\Delta_{m} V\left(\mathrm{~cm}^{3} / \mathrm{g}\right)\end{array}$ \\
\hline 0.00000 & 0.806153 & 0.806153 & 0.000000 \\
\hline 0.09652 & 0.835269 & 0.833948 & +0.001321 \\
\hline 0.21324 & 0.869978 & 0.867560 & +0.002418 \\
\hline 0.38633 & 0.920669 & 0.917406 & +0.003263 \\
\hline 0.51777 & 0.958613 & 0.955256 & +0.003357 \\
\hline 0.73385 & 1.019972 & 1.017481 & +0.002491 \\
\hline 0.87610 & 1.059780 & 1.058445 & +0.001335 \\
\hline 1.00000 & 1.094125 & 1.094125 & 0.000000 \\
\hline
\end{tabular}

表-7 大豆油一 1,1,2,2-四塩化エタン系混合容積 $\left(30.0^{\circ} \mathrm{C}\right)$

\begin{tabular}{|c|c|c|c|}
\hline $\begin{array}{c}\text { 大豆油 } \\
\text { 重量分率 } \\
w\end{array}$ & $\begin{array}{l}\text { 比 容 積 } \\
\text { (実測値) } \\
V\left(\mathrm{~cm}^{3} / \mathrm{g}\right)\end{array}$ & $\begin{array}{l}\text { 理想溶液 } \\
9 \text { 比容積 } \\
V^{i}\left(\mathrm{~cm}^{3} / \mathrm{g}\right)\end{array}$ & $\begin{array}{c}\text { 混合に伴 } \\
\text { 容積変化 } \\
\Delta_{m} V\left(\mathrm{~cm}^{3} / \mathrm{g}\right)\end{array}$ \\
\hline 0.00000 & 0.633014 & 0.633014 & 0.000000 \\
\hline 0.13865 & 0.696218 & 0.696944 & -0.000726 \\
\hline 0.25164 & 0.747906 & 0.749042 & -0.001136 \\
\hline 0.36532 & 0.800146 & 0.801458 & -0.001312 \\
\hline 0.51010 & 0.866818 & 0.868214 & -0.001396 \\
\hline 0.80991 & 1.005607 & 1.006452 & -0.000845 \\
\hline 1.00000 & 1.094100 & 1.094100 & 0.000000 \\
\hline
\end{tabular}


表-8 大豆油一二硫化炭素系混合容積 $\left(30.0^{\circ} \mathrm{C}\right)$

\begin{tabular}{c|c|c|c}
\hline $\begin{array}{c}\text { 大豆 油 } \\
\begin{array}{c}\text { 重量分率 } \\
w\end{array}\end{array}$ & $\begin{array}{c}\text { 比 容 皘 } \\
\left(\begin{array}{c}\text { (実湘値 }) \\
V\left(\mathrm{~cm}^{3} / \mathrm{g}\right)\end{array}\right.\end{array}$ & $\begin{array}{c}\text { 理想溶液 } \\
\begin{array}{c}\text { 比容皘 } \\
V^{i}\left(\mathrm{~cm}^{3} / \mathrm{g}\right)\end{array}\end{array}$ & $\begin{array}{c}\text { 混合飞伴 } \\
\text { 容積変化 } \\
{ }_{m} V\left(\mathrm{~cm}^{3} / \mathrm{g}\right)\end{array}$ \\
\hline 0.00000 & 0.80192 & 0.80192 & 0.00000 \\
0.12912 & 0.84167 & 0.83959 & +0.00208 \\
0.23327 & 0.87358 & 0.86997 & +0.00361 \\
0.40139 & 0.92342 & 0.91901 & +0.00441 \\
0.58267 & 0.97648 & 0.97190 & +0.00458 \\
0.74063 & 1.02167 & 1.01798 & +0.00369 \\
0.86654 & 1.05725 & 1.05470 & +0.00255 \\
1.00000 & 1.093631 & 1.093631 & 0.000000 \\
\hline
\end{tabular}

表-9 大豆油一クロロホルム系混合容積 $\left(30.0^{\circ} \mathrm{C}\right)$

\begin{tabular}{|c|c|c|c|}
\hline $\begin{array}{c}\text { 大豆油 } \\
\text { 重量分率 } \\
w\end{array}$ & $\begin{array}{l}\text { 比 容 積 } \\
\text { (実测値) } \\
V\left(\mathrm{~cm}^{3} / \mathrm{g}\right)\end{array}$ & $\begin{array}{l}\text { 理想溶液 } \\
\text { 比容皘 } \\
V^{i}\left(\mathrm{~cm}^{3} / \mathrm{g}\right)\end{array}$ & $\begin{array}{c}\text { 混合飞伴 弓 } \\
\text { 容積変化 } \\
{ }_{m} V\left(\mathrm{~cm}^{3} / \mathrm{g}\right)\end{array}$ \\
\hline 0.00000 & 0.679791 & 0.679791 & 0.000000 \\
\hline 0.09263 & 0.717337 & 0.718148 & -0.000811 \\
\hline 0.14776 & 0.739697 & 0.740976 & -0.001279 \\
\hline 0.20549 & 0.763417 & 0.764881 & -0.001464 \\
\hline 0.29202 & 0.798913 & 0.800712 & -0.001799 \\
\hline 0.44504 & 0.861972 & 0.864075 & -0.002103 \\
\hline 0.55327 & 0.906883 & 0.908891 & -0.002008 \\
\hline 0.66325 & 0.952618 & 0.954432 & -0.001814 \\
\hline 0.83990 & 1.026374 & 1.027580 & -0.001206 \\
\hline 0.91101 & 1.056251 & 1.057026 & -0.000775 \\
\hline 1.00000 & 1.093875 & 1.093875 & -0.000000 \\
\hline
\end{tabular}

表-10大豆油一トリクロルエチレン系混合容積 $\left(30.0^{\circ} \mathrm{C}\right)$

\begin{tabular}{|c|c|c|c|}
\hline $\begin{array}{c}\text { 大豆油 } \\
\text { 重量分率 } \\
w\end{array}$ & $\begin{array}{l}\text { 比容 皘 } \\
(\text { 実測值 }) \\
V\left(\mathrm{~cm}^{3} / \mathrm{g}\right)\end{array}$ & $\begin{array}{c}\text { 理想溶液 } \\
\text { 此容皘 } \\
V^{i}\left(\mathrm{~cm}^{3} / \mathrm{g}\right)\end{array}$ & $\begin{array}{c}\text { 混合飞伴 } 5 \\
\text { 容積変化 } \\
\Delta_{m} V\left(\mathrm{~cm}^{3} / \mathrm{g}\right)\end{array}$ \\
\hline 0.00000 & 0.690833 & 0.690833 & 0.000000 \\
\hline 0.14816 & 0.749718 & 0.750569 & -0.000851 \\
\hline 0.25769 & 0.793436 & 0.794730 & -0.001294 \\
\hline 0.50420 & 0.892482 & 0.894119 & -0.001637 \\
\hline 0.59118 & 0.927580 & 0.929188 & -0.001608 \\
\hline 0.76930 & 0.999739 & 1.001008 & -0.001269 \\
\hline 0.84978 & 1.034370 & 1.033452 & -0.000918 \\
\hline 1.00000 & 1.094019 & 1.094019 & 0.000000 \\
\hline
\end{tabular}

表-11 大豆油一䣷酸エチル系混合容積 $\left(30.0^{\circ} \mathrm{C}\right)$

\begin{tabular}{|c|c|c|c|}
\hline $\begin{array}{c}\text { 大豆油 } \\
\text { 重量分率 } \\
w\end{array}$ & $\begin{array}{l}\text { 比 容 積 } \\
(\text { 実測值) } \\
V\left(\mathrm{~cm}^{3} / \mathrm{g}\right)\end{array}$ & $\begin{array}{l}\text { 理想溶液 } \\
\text { 比容皘 } \\
V^{i}\left(\mathrm{~cm}^{3} / \mathrm{g}\right)\end{array}$ & $\begin{array}{c}\text { 混合飞伴 } 5 \\
\text { 容積変化 } \\
\Delta_{m} V\left(\mathrm{~cm}^{3} / \mathrm{g}\right)\end{array}$ \\
\hline 0.00000 & 1.125808 & 1.125808 & 0.000000 \\
\hline 0.13625 & 1.122102 & 1.121471 & +0.000631 \\
\hline
\end{tabular}

\begin{tabular}{l|r|r|r}
0.29836 & 1.117445 & 1.116310 & +0.001135 \\
0.49017 & 1.111570 & 1.110204 & +0.001366 \\
0.64983 & 1.106403 & 1.105121 & +0.001282 \\
0.81230 & 1.100873 & 1.099949 & +0.000924 \\
1.00000 & 1.093974 & 1.093974 & 0.000000 \\
\hline
\end{tabular}

表-12 大豆油一アセトン系混合容積 $\left(30.0^{\circ} \mathrm{C}\right)$

\begin{tabular}{|c|c|c|c|}
\hline $\begin{array}{l}\text { 大豆油 } \\
\text { 重量分率 } \\
w\end{array}$ & $\begin{array}{l}\text { 毕 容 積 } \\
(\text { 実測值) } \\
V\left(\mathrm{~cm}^{3} / \mathrm{g}\right)\end{array}$ & $\begin{array}{l}\text { 理想溶液 } \\
9 \text { 比容積 } \\
V^{i}\left(\mathrm{~cm}^{3} / \mathrm{g}\right)\end{array}$ & $\begin{array}{c}\text { 混合に伴う } \\
\text { 容積変化 } \\
\Delta_{m} V\left(\mathrm{~cm}^{3} / \mathrm{g}\right)\end{array}$ \\
\hline 0.000 & 339 & 1.27 & 000 \\
\hline 0.20236 & 1.239545 & 1.239766 & -0.000221 \\
\hline 0.37242 & 1.208053 & 1.208611 & -0.000558 \\
\hline 0.57649 & 1.170553 & 1.171225 & -0.000672 \\
\hline 0.77936 & 1.1 & 1.1 & -0.000486 \\
\hline 1.00000 & 1.093636 & 1.093636 & 0.000000 \\
\hline
\end{tabular}

\section{5. 考察}

混合溶液に関季る理論は括よそつぎの二つに分類する ことができる。第一は格子模型とよる理論で, Hildebrand $^{18\rangle}$ そよって提出され, Fowler や Guggenheim $ら^{199,20)}$ とよって発展したいわゆる正則溶液の理論がこ れである。第二は格子模型とよらない理論で, Longuet -Higgins の conformal solution ${ }^{21)}$ や, Prigogine の cell 模型22) とよるものである。これらの理論はいずれ も，分子間ポテンシァルを分子間距離の関数として与え て分配関数を計算するものであるから，第一の格子模型 の理論よりある点では進んでいるが，それでもな扰垁験 と満足な一致を示すに至っていない。特に油脂のような 複雑な分子を成分侍つ溶液では, その理論的取扱いが はなはだ困難となるのでここでは簡単な考察を行なうに 止める。

さて, 本実験で得た $\Delta_{m} V$ の值と, Jhonston ${ }^{1)}$, Magne, Skau $5^{91,10), 11,12)}$ 飞よって得られた值を比軦 のために 図-2〜図-5 亿示す。文献より引用した值住, 本実験と溶媒が同じでかつ測定温度ならびと油脂の性質 が似か上った系の夕を選んだ。

図-1 からわかるように， $\Delta_{m} V$ が極大または極小代 なる点は Skau, Magne らが指摘したと扔り ${ }^{12)}$, 重量 分率でほぼ 0.5 の点にあって著しく片寄ることはないの であるが，必ずしも中央になく，末たそこを中心とする 放物線にもなっていない。しかし，概略的飞い党ば， Skau らの指摘は正しいのであって，これはつぎのよう 飞考光ればよからう。すなわち，いま溶液は準格子模型 を作り，油脂と溶媒とはそれぞれその格子点を占めると する。そしてそれらの分子容の比を $r$ とし, 溶媒分子 1 個が一つの格子点を占めるとき, 油脂分子 1 個は $r$ 個の 格子点を占めるとする。さらに，各格子点に扔ける cell 
の自由体積の増減が，油脂と溶媒とを混合したとき，そ れら飞配分される格子点の割合飞従うものとすれば，分 子間飞特別反強い力が作用せず，かつそれらの密度があ まり違わない限り, $\Delta_{m} V$ の極值は重量率でほぼ 0.5 の

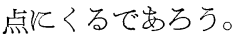

このような仮定は，混合される両分子の性質が似てい て，その大きさだけが異なるときに満足さるべきるのと 思われる。たとえば van der Waals は炭素数の異なった 二種の飽和炭化水素を混合して $\Delta_{m} V$ を測定した ${ }^{23)}$ が， $\Delta_{m} V$ を重量分率として計算しな扮せば，その極值はほ ほ虫央にくるようになる。しかし, 油脂一溶媒系の場合 は, かりと溶媒が無極性であってる，油脂が極性を持っ て和り，ま炏溶液の成分分子相互の性質が異なるから，上 の仮定からはずれて $\Delta_{m} V$ の極值が中央からずれると想 像される。また特極性の大きい溶媒, たと兄げク口ロ ホルム,トリクロルエチレン,アセトンなどを使ったとき は，極值が中央からずれる傾向はさらに大きいと考光ら れるのであるが，実験の結果は予想と異なって極端なず れは見られない。これは, このような系に扬いては油脂 の極性はあまり問題とならず，油脂と溶媒分子との間の 交渉は，主として油脂のアルキル部と溶媒との間で行な

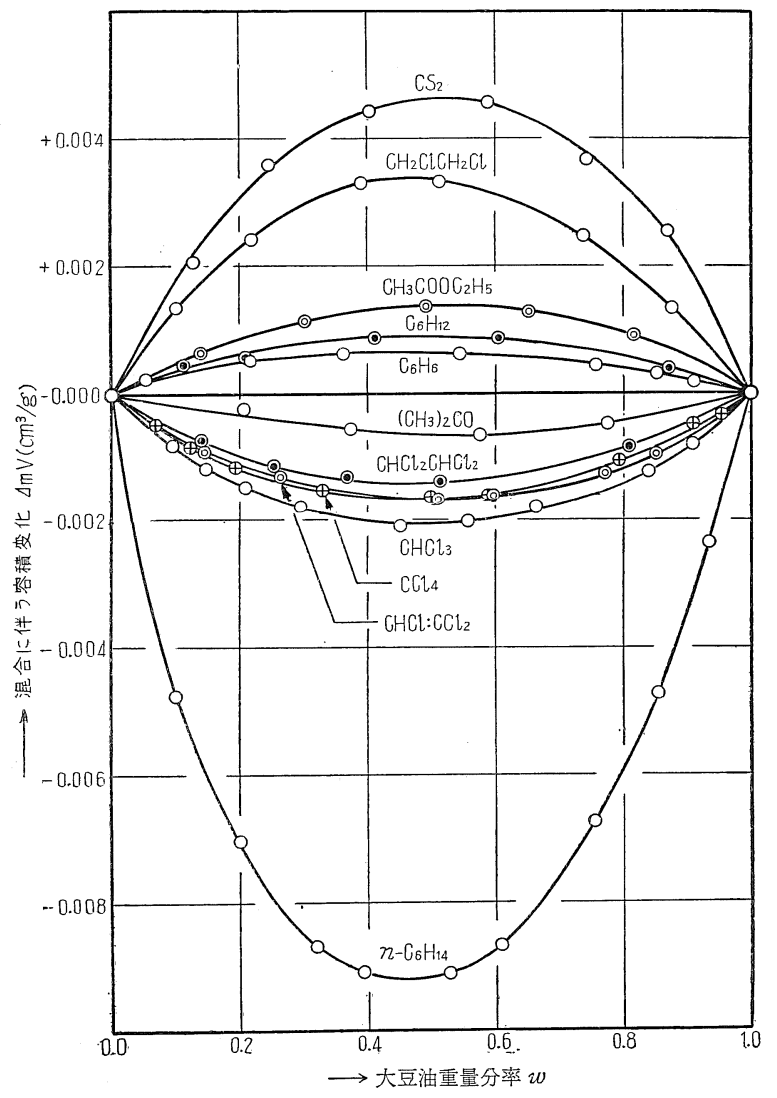

図-1 大豆油一溶媒系の混合飞伴う容積変化 $\left(30.0^{\circ} \mathrm{C}\right)$
われるととを意味するものと考光られる。つまり溶液中 の扔の扔のの格子点は, 1 個ずつの溶媒分子と, $1 / r$ 個 ずつの油脂分子とで占められるという上の仮定が，ほぼ 満足されているととを示するのであらう。

このととはなたつぎのような事実からもいうことがで きる。すなわち, 油脂抒よび溶媒の相刘偏比容積 $\Delta / V_{1}$, $\Delta / V_{2}$ を，それぞれ油脂分率 $w=0$ 执よび $w=1$ の点飞 扬いて計算すれば，これは油脂または溶媒 $1 \mathrm{~g}$ ガ同種分 子同志の結合から完全飞切り離されて, 他の分子から取 り团まれたときの容積変化量を示すものであって, 溶媒 の種類を問わずこの一対の值はほとんど相等しい。すな わち油脂と溶媒との間飞重量飞扔いてほぼ $1: 1$ の当量 関係の存在することを意味する。ただし，これらの議論 は常飞油脂と溶媒との密度の差異を考慮して行なうべき であって，乙れを考光机ば，この当量関係は重量上りも， むしろ容積とついて成立すべきるのと推察される。

しかしそれぞれな招完全には説明できない点があるの であって，この現象を説明するためには，上の仮定を少 し変更するとともに, 混合溶液中に招ける分子の充テン 状態, つまり隣接格子点の数が油脂の濃度とともに変る ことや，また油脂分子がある連続した構造を持ったるの であるなどの效果を入れて考光る必要があるう。

つぎと $\Delta_{m} V$ の值は，溶媒の種類によって正または 負の種々な值をとるが，概略的にい光ば，油脂を無極、 性溶媒と混合すれば膨張し，極性溶媒と混合すれば収 縮する。しかしいずれの場合も例外があって，四塩化 炭素, 四塩化エタン, $n$-ヘキサンの場合は無極性であ. っても収縮し, 酶酸エチルは極性溶媒であっても膨張 している。

一般的にい光ば, 混合飞伴う容積変化 $\Delta_{m} V$ は, エ ネルギー変化，つまり混合熱の符号と大きさとに支配 される。すなわち, 二種の液体が混合されて均一な溶 液を作るとき，異種分子間の結合エネルギーが，成分 分子同志の間の結合エネルギーの平均值より大であれ ば，混合に際してエネルギーを放出し，より安定な溶 液となると同時飞, 分子間距離も成分が単独忆存在す るときより小となるであろう。逆混合に際して熱を 吸収するような系では分子間距離も増大するであろろ から，発熱と収縮，吸熱と膨張とが相伴うことになる。

たと党ば, ベンゼンと四塩化炭素とはともに無極性

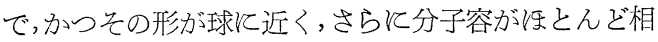
等しい、もかかわらず，大豆油をべンゼンと混合すれ ば膨張し，四塩化炭素と混合すれば収縮する。これは 両者の場合の混合熱の符号が異なるからであって，前 者の場合では吸熱であり，後者のときは発熱である からに法かならない。

ここで興味のあることは，大豆油をnーへキサンと混 合したときの容積変化である。この系の混合熱は，大 


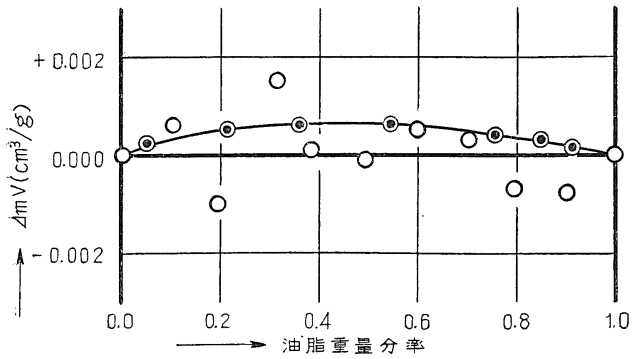

(0)大豆油一ベンゼン系 $\left(30.0^{\circ} \mathrm{C}\right)$ (本実験) ○綿実油一ベンゼン系 $\left(25^{\circ} \mathrm{C}\right.$ ) (文献 12 )

図-2 大豆油一ベンゼン, 綿実油一ベンゼン系 混合容積

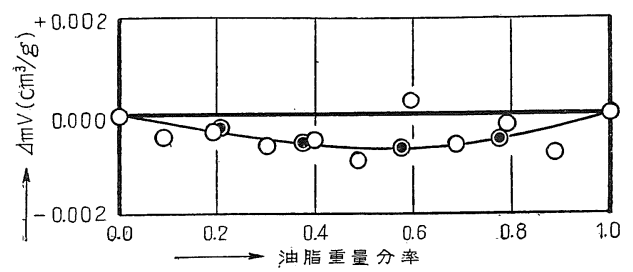

○大豆油一アセトン系 $\left(30.0^{\circ} \mathrm{C}\right.$ ) (本実験) ○綿実油一アセトン系 $\left(25^{\circ} \mathrm{C}\right.$ ) (文献 9 )

図-3 大豆油一アセトン, 綿実油一アセトン系 混合容積

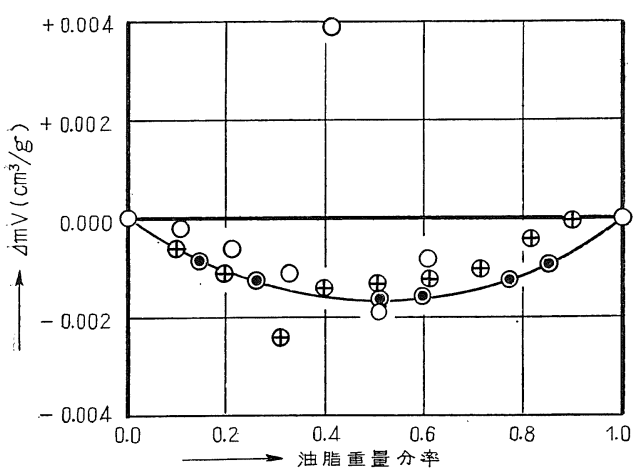

○大豆油一トリクロルエチレン系 $\left(30.0^{\circ} \mathrm{C}\right.$ ) (本実験) ○大豆油一トリクロルエチレン系 $\left(25^{\circ} \mathrm{C}\right.$ ) (文献 1)

(粗綿実油一トリクロルエチレン系 $\left(30^{\circ} \mathrm{C}\right)$ （交献 10)

図-4 大豆油一トリクロルェチレン, 粗綿実油一 トリクロルエチレン系混合容積

豆油一ベンゼン系とほぼ同じ程度のわずかな吸熱である 飞るかかわらず3), $\Delta_{m} V$ は負で, しか子異常に大きな值 を示す。Skau ら ${ }^{12)}$ \& n-ペンタンから n-デカンに至る 直鎖状炭化水素と油脂との混合容積の変化を, $10 \sim 60^{\circ} \mathrm{C}$ の範囲で測定して，炭素数が少ない质ど，また温度が高い ほぞ収縮量が多いことを指摘した。したがって溶媒の炭 素数がさらに多ければ，これと逆に膨張を起すことが想 像されるのであるが, 事実 $30.0^{\circ} \mathrm{C}$ 亿拉いて大豆油と流 動パラフィンとを同重量ずつ混合すれば0.000073 $\mathrm{cm}^{3} / \mathrm{g}$

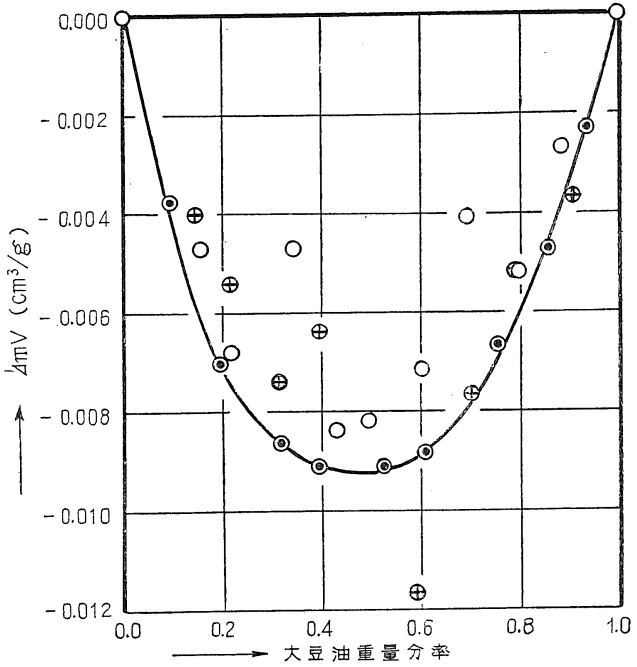

○大豆油一 $n$-ヘキサン系 $\left(30.0^{\circ} \mathrm{C}\right.$ ) (本実験)

○大豆油一Skelysolve B 系 $\left(25^{\circ} \mathrm{C}\right.$ ) (文献 9 )

甲大豆油一 $n$-ヘキサン系 $\left(25^{\circ} \mathrm{C}\right)$ （文献 1 )

図-5 大豆油一 $n$-ヘキサン系混合容積

の容積膨張を示すのがみられた。

油脂一炭化水素系と同じような現象は，これまで漠然 と理想溶液を作ると考えられていた，炭素数の異なった 二種の直鎖炭化水素の混合系に特いても見られるのであ って, 混合される二種の炭化水素の炭素数の差が大きい 臣ど吸熱が大きく24)，25)，かつ大きな容積収縮を示す23)。 たとえば， $n$-ヘキサン一n-ヘキサデカン系の $20^{\circ} \mathrm{C}$ に掠 ける混合熱の值は Bronsted が測定しているが24)，これ から重量分率 0.5 飞持ける值を推定すれば, $0.19 \mathrm{cal} / \mathrm{g}$ の吸熱であって，また同じ温度抽よび濃度に和ける混合 容積は, van der Waals ${ }^{23)}$ の測定から $0.00042 \mathrm{~cm}^{3} / \mathrm{g}$ の 収縮を示すことがわかる。

van der Waals は，このような直鎖炭化水素の二成 分等モル混合溶液の容積変化 $\Delta_{m} V_{v=0.5}$ が, つぎの実 験式で与えられることを示した ${ }^{23)}$ 。

$$
\Delta_{m} V_{w=0.5}=k\left(\frac{1}{K_{1}+1}-\frac{1}{K_{2}+1}\right)^{2}
$$

ここで $k$ は温度のみに関する定数, $K_{1}, K_{2}$ はとれぞれ 成分の炭素原子数である。

いま，この式を使って，n-ヘキサン一nーオクタデカ ン系の $\Delta_{m} V_{w=0.5}$ を求め, さらにこれから等重量混合溶 液の $30^{\circ} \mathrm{C}$ と括ける $\Delta_{m} V$ の值を推定すれば, この系 は $0.008 \mathrm{~cm}^{3} / \mathrm{g}$ の収縮を示すことになる。大豆油が主と して $\mathrm{C}_{18}$ 脂肪酸のグリセリドであることを考えれば，大 豆油一nーヘキサン系について本実験で得られた重量分率 0.5 の点飞抬ける容積収縮量 $0.0092 \mathrm{~cm}^{3} / \mathrm{g}$ と, 上記の 推定值 $0.008 \mathrm{~cm}^{3} / \mathrm{g}$ との一致は偶然のことであるとは思 われない。両者間の約 $10 \%$ の差は, 油脂がグリセリド 
でありかつ不飽和結合を持つなどのことによるるのと考 壳れば，油脂と直鎖炭化水素とからなる混合溶液の場合 る, 油脂分子が溶媒分子との間に行なら交路は, るっね゚ ら油脂のアルキル部が主役を演じているものとしてよか ろう。

Hildebrand $^{18)}$ や Longuet-Higgins ${ }^{21)}$ とよれば, 混 合飞伴亏容積変化 $\Delta_{m} V$ は, 成分の圧縮率 $\kappa$ の関数と して与兄られる。これは容積が内部エネルギーの圧力に 関する偏微係数で与兄られることに由来する。したがっ て一般と， $\Delta_{m} V$ はつぎのよう澅くことができる。

$$
\Delta_{m} V=A+B \kappa
$$

ここで $A, B$ はそれぞれ濃度, 圧力, 温度などを含む 関数であるが，いまかりにこれらを一定とすれば， $\Delta_{m} V$ は $\kappa$ 亿比例することとなる。溶媒の圧縮率の信頼できる 值は少ないが, 直鎖炭化水素については van der Waals が, 比熱, 膨張係数, 密度招よび音速度から $20^{\circ} \mathrm{C}$ 飞招

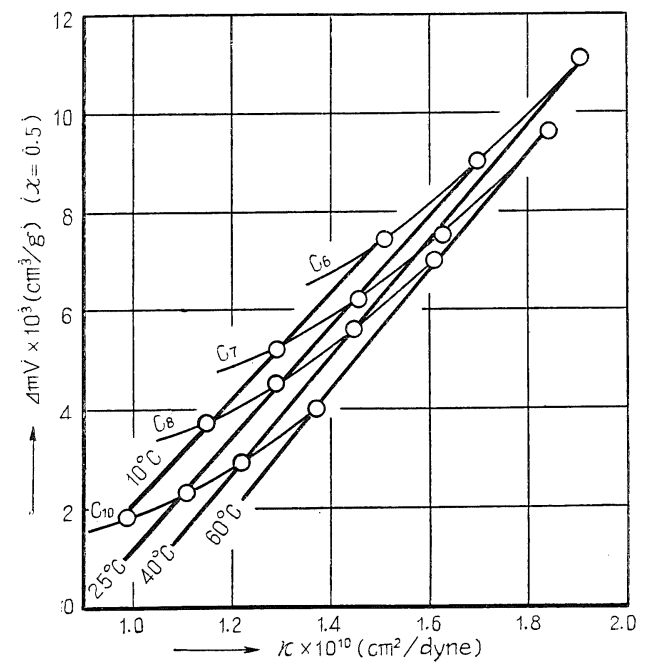

図-6 油脂一直鎻炭化素系の混合飞伴 う容積変 化と, 溶媒の圧縮率との関係

ける て各温度飞却忛る $几$ を計算し，一方 Skau らの $w=0.5$ そ招ける $\Delta_{m} V$ の值とから，両者の関係を示したのが 図-6であって, 上式の関係がよく満足されているとと がわかる。図中 $\mathrm{C}_{6}, \mathrm{C}_{7}, \mathrm{C}_{8}, \mathrm{C}_{10}$ などと示したのは, 油脂 の溶媒がそれぞれ $n$-ヘキサン, $n$-ヘプタン， $n$-オクタ ン, $n$-デカンであるととを意味する。同一溶媒であって も，温度が上昇すれば圧縮率が増加するから， $\Delta_{m} V$ も

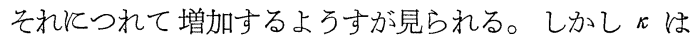

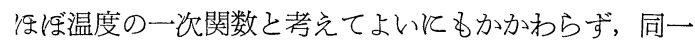
容媒についての $\pi$ と $\Delta_{m} V$ とが直線関係を示さないの は, 温度の上昇飞伴って溶液中の分子の運動が激しくな り，そのために混合の状態が変化するためであるうと考
えられる。

また大豆油を四塩化炭素, トリクロルエチレン, クロ ロホルムなどと混合すれば，この順序で混合熱が大とな っていて, 大豆油一クロロホルム系は大豆油一四塩化炭 素系の約 8 倍の発熱を示す3)。それ《もかかわらず， こ れらの $\triangle \mathrm{mV}$ の值は注とんど等しく, 最大約 $20 \%$ の差 しか見られないで，容積の収縮には混合熱と異なっため る限度のあることを思わせる。すなわち異種分子間の結 合力に比例して分子間距離は小さくならないのであって これも炭化水素のときと同様溶, 溶媒の圧縮率に上るも のであると考えられる。トリクロルエチレンとついての 圧縮率の值は見当らないが，四塩化炭素招よびクロロホ ルムの圧縮率は $20^{\circ} \mathrm{C}$ と拝いてそれぞれ 1.04 招上び $0.95 \times 10^{-10} \mathrm{~cm}^{2} / \mathrm{dyne}$ であっで ${ }^{26)}$, 両者の值は统潘相等 しいので, これらの場合の容積の収縮がはぼ゙同じ大きさ そなるものと考劣てよいと思われる。

最後飞本研究を行なら飞当って常飞御指導御鞭鞋下さ った宮崎大学工学部宮崎兄一教授, ならびそ九州大学工 学部坂井渡教授飞厚く御礼申上げる.

(昭和 33 年 3 月 10 日受理)

\section{文献}

1) H.F. Jhonstone, I.H. Spoor, W.H. Goss, Ind . Eng. Chem., 32, 832 (1940)

2) G. Gee, W.J.C. Orr, Trans. Faraday Soc., 42, 507 (1946)

3) 草野, 本誌, 7, 406 (1958)

4) E.F. Pollard, H.F.L. Vix, E.A. Gastrock, Ind. Eng. Chem., 37, 1022 (1945)

5) A.S. Smith, F.J. Wechter, J. Am. Oil Chemists' Soc., 27, 381 (1950)

6) A.S. Smith, ibid., 28, 356 (1951)

7) A.S. Smith, B. Florence, ibid., 28, 360 (1951)

8）草野, 宮崎, 日化第 10 年会講演（昭32）

9) F.C. Magne, E.L. Skau, Ind. Eng. Chem., 37, 1097 (1945)

10) F.C. Magne, E.J. Huges, E.L. Skau, J. Am. Oil Chemists' Soc., 27, 552 (1950)

11) F.C. Magne, R.L. Durr, E.L. Skau, ibid., 30, 8 (1953)

12) E.L. Skau, F.C. Magne, R.R. Mod, R.L. Durr, Ind. Eng. Chem., 47, 1043 (1955)

13）宮崎, 工業化学会第 46 年会（昭 18）; 日化第 2 年 会 (昭 24)

14) L.K. Alnord, J. Am. Oil Chemists' Soc., 30, 81 (1953)

15) International Critical Table, Vol.III (1923); Weissberger, "Technique of Organic Chemistry", Vol.I Physical Method part 1 (1952)

16）草野, 宮崎大学工学部研究報告, 4, (昭 33) 
17) Weissberger, "Technique of Organic Chemistry”, VII; “Organic Solvents” (1955); 桑田, “溶剂”，丸善 (昭 26)

18) J.H. Hildebrand, R.L. Scott, "The Solubility of Nonelectrolytes" (1950); J.H. Hildebrand, J. Am. Chem. Soc.,51, 66 (1929)

19) R.H. Fowler, E.A. Guggenheim, "Statistical Thermodynamics" (1939), (1956)

20) E.A. Guggenheim, "Mixtures" (1952)

21) H.C. Longuet-Higgins, Proc. Roy. Soc., A 205, 247 (1952)
22) I. Prigogine, A. Bellemans, Discussion of Faraday Soc., No.15, 80 (1953); I. Prigogine, A. Bellemans, A. Englert-Chwoles, J. Chem. Phys., 24, 518 (1956)

23) J.H. van der Waals, 私信; Rec. trav. chim., 77, 53 (1958)

24) J.N. Bronsted, J. Koefoed, Kgl. Danske Vid. Selsk., 22, No.17,1 (1946)

25) J.H. van der Waals, Trans. Faraday Soc.r 52, 916 (1956)

26）芝，“物理常数表”，岩波書店（昭 23）

\section{油脂と溶媒との混合熱}

草一野一仁*

\section{Heats of Mixing of Fatty Oil with Various Solvents.}

Kazuhito Kusano

\section{1. 緒言}

油脂と溶媒とよりなる系の示す物理化学的諸性質の測 定は, 単飞学問上のみならず, 工業上飞和いても重要な 基礎的数值を与光るるのであるとるかかわらず，從来研 究の最も手薄な部門であった。なかでも混合熱の測定は， 混合溶液の蒸気圧の測定とともと，系の熱力学的特性を 決定する上飞必要欠くべからざるものであるが，わずか に一，二の報告があるに過ぎない。たとえばJhonstone $ら^{1)}$ は大豆油を各種の溶媒と等重量ずつ混合して, その ときの温度変化を定性的飞調べ，また Ferry ${ }^{2)}$ はオリ ーブ油一ベンゼン系の混合熱を $16^{\circ} \mathrm{C}$ 亿括いて3つの濃 度て測定して，その希釈熱 $\Delta H_{0}$ が

$$
\triangle H_{0}=250 v^{2} \mathrm{cal} / \mathrm{mol}
$$

で与兄られるととを示した。ここで vはオリーブ油の 容積分率である。

著者は油脂抽出工業に㧍ける基礎数值を得るととも 飞, 油脂一溶媒系の熱力学的特性を明らか沉する目的で, 油脂を各種の溶媒と混合したときの混合熱孝, $30.0^{\circ} \mathrm{C}$ 亿 扔いて全濃度範囲にわたって精密飞測定したので，その 結果について報告する。

\section{2. 実験 装置}

熱量計としてはジュワービンを使い，恒温怙よび断熱 熱量計として両用できるものを考案した。すなわち恒温 熱量計は図-1 と示すよう火, 内径 $6 \mathrm{~cm}$, 深さ $15 \mathrm{~cm}$,

* 宮崎大学工学部工業化学教室 (宮崎市西丸山町) Faculty of Engineering, Miyazaki University。
内容約 $400 \mathrm{cc}$ のジュワービンと, ピペット, 電熱器, カキマゼ機怙よび示差熱電対を取り付けたるのである。 そのフタはジュワービンとスリ合ワセになっていて，そ の内部はジュワービンと同様に銀メッキしてのち真空に してある。ピペットは測定を始める前に混合すべき液体 のいずれか一方を入れて招くもので, $0.2 \mathrm{~mm}$ 厚の銅板 から作った縦長のドーナツ型, 内容約 $90 \mathrm{cc}$ のので,

上下に径 $2.5 \mathrm{~mm}$ の銅管が付けてある。ピペットの外

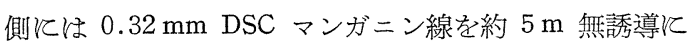
巻いてこれを電熱器の電熱線とする。電熱線の両端には それぞれ電圧招よび電流導線を銀口辛付けし，これらと はベークライトワニスを塗ったのち $160^{\circ} \mathrm{C} て ゙$ 焼き付け て, 電気的に絶縁した。電圧招よび電流導線は熱量計の フタを通って外部へ導くが，導線を通って熱量計中熱 が出入するのを防ぐために，これらにビニル管をかぶせ て恒温りウ中を通してから計測器へ導いた。

カキマゼ機はガラス製プロペラ型, 翼幅 $8 \mathrm{~mm}$, 翼長 $20 \mathrm{~mm}$ のものを $45^{\circ}$ そひねったもので, 注射筒型スり 合ワセでフ夕を貫いている。プロペラはピペットを熱量 計内に納めたとき，ピペットの下端にくるように取り付 け，かつ液を吸上げる方向に回転した。したがって液は ピペットの中央部を上昇し，その外側とジュワービンの 間を下降するから，液は上くかきまぜられ，ピペットの温 度を速か飞一様㣙る。おたカキマゼ速度が $150 \mathrm{rpm}$ 以下ではジュール熱の影響は見られなかった。したがっ て測定の場合は通常この速度でかきまぜたが, 高濃度溶 液を取り披う場合，すなわち油脂中飞少量の溶媒を加兄 るときは，混合の不均一が起るのを防ぐために，特にカ 